\title{
Perlindungan Hukum Persaingan Usaha Terhadap Indikasi \\ Persekongkolan Tender Jack Up Drilling Rig Services Antara HUSKY-CNOOC MADURA LIMITED Dengan PT COSL INDO (Analisis Putusan KPPU No. 03/KPPU-L/2016)
}

\author{
Suradiyanto $^{1}$, Dinny Wirawan Pratiwie ${ }^{2}$ \\ suradiyanto70@gmail.com, Universitas Mulawarman, Indonesia ${ }^{1}$ \\ dinipratiwie@gmail.com, Universitas Widya Gama Mahakam, Indonesia ${ }^{2}$
}

\begin{abstract}
Conspiracy use various way for coordinate activities they like through settings production, determination price horizontally, collusive tendering, division area, division consumer as a non-territorial, and division share market, even though similarly we need realize it that effective conspiracy it is not easy for achieved. However there trend the perpetrators business will always attempted maximizing profit his company respectively. Must there is some requirement in occurrence a conspiracy is must existence deal agreement or collusion between perpetrators effort. There is two form collusion in conspiracy, namely: collusion explicit, where the member communicate and coordinate deal they on real/live can declared with some document agreement already they agree, the data regarding the joint audit, management conspiracy, policies-policies writing, sales data and other data. There is also collusion secretly, where the perpetrators business member conspiracy no communicate on blatant, usually meetings too held on secret. And regular use as the media is association industry, so meetings member conspiracy camouflaged with legal meetings such as meeting associations. Form the second collusion this very difficult for detected by enforcer law. However experience from various country prove that at least $30 \%$ of conspiracy is involve associations.
\end{abstract}

Keywords: Protection of Competition Law; Indications Conspiracy.

\begin{abstract}
Abstrak
Konspirasi menggunakan berbagai cara untuk mengoordinasikan kegiatan dalam hal pengaturan produksi, penentuan harga secara horizontal, tender kolusif, area divisi, konsumen devisi sebagai non-teritorial, dan pangsa pasar divisi, meskipun demikian kita perlu menyadari bahwa konspirasi yang efektif itu tidak mudah dicapai. Namun ada kecendrungan pelaku bisnis akan berusaha memaksimalkan keuntungan perusahaan. Beberapa syarat terjadinya persekongkolan adalah ada kesepakatan atau kolusi antara pelaku usaha. Ada dua bentuk kolusi dalam konspirasi yaitu: kolusi eksplisit, dimana anggota berkomunikasi dan mengoordinasikan kesepakatan secara nyata/langsung dapat dideklarasikan dengan beberapa dokumen perjanjian yang sudah mereka setujui, data mengenai audit bersama, konspirasi manajemen, kebijakan-kebijakan tertulis, data penjualan dan data lainnya. Ada pula kolusi secara tersembunyi, dimana para pelaku konspirasi yang merupakan anggota dalam bisnis tersebut tidak berkomunikasi secara terang-terangan, rapat dilaksanakan secara tertutup. Dan biasanya yang digunakan sebagai media adalah asosiasi industri. Sehingga rapat konspirasi anggota disamarkan melalui pertemuan hukum seperti pertemuan asosiasi. Bentuk kolusi kedua ini sangat sulit untuk dideteksi oleh penegak hukum. Namun di beberapa negara terbukti setidaknya 30\% konspirasi yang terjadi melibatkan asosiasi.
\end{abstract}

Kata kunci: Perlindungan terhadap Hukum Persaingan Usaha; Indikasi Konspirasi 
Perlindungan Hukum Persaingan Usaha Terhadap

Indikasi Persekongkolan Tender Jack Up Drilling

Rig Service Antara Husky-CNOOC Madura Limited

dengan PT. COSL INDO

Suradiyanto; Dinny Wirawan

Pratiwie

DOI $|:|$ https://doi.org/10.24903/yrs.v12i1.824

\begin{tabular}{|l|l|l|}
\hline Received & $:$ & Januari 2020 \\
\hline Accepted & $:$ & Januari 2020 \\
\hline Published & $:$ & Februari 2020 \\
\hline & $\begin{array}{l}\text { Authors retain copyright and grant the journal right of first publication with the } \\
\text { work simultaneously licensed under a Creative Commons Attribution 4.0 } \\
\text { International License that allows others to share the work with an acknowledgement of }\end{array}$ \\
Copyright Notice & $:$ & \begin{tabular}{l} 
the work's authorship and initial publication in this journal. \\
\hline
\end{tabular}
\end{tabular}

Copyright Notice the work's authorship and initial publication in this journal.

\section{PENDAHULUAN}

Perkembangan sistem hukum di negara Indonesia salah satunya dibidang hukum ekonomi yaitu hukum persaingan usaha. Hukum persaingan usaha bertujuan untuk mencegah praktek monopoli dan/atau persaingan usaha tidak sehat yang dilarang. Sejarah praktek monopoli di negara Indonesia pertama kali secara resmi berawal pada tanggal 20 Maret 1602, yaitu saat Pemerintah Belanda atas persetujuan State General memberikan hak untuk berdagang sendiri pada VOC di wilayah Indonesia. ${ }^{1}$

Arie Siswanto berpendapat dalam bukunya yang berjudul Hukum Persaingan Usaha yang dimaksud dengan hukum persaingan usaha (Competition Law) adalah instrumen hukum yang menentukan tentang mekanisme persaingan harus dilakukan. Hukum persaingan secara khusus menekan pada bagian aspek "persaingan" sehingga pelaku usaha tidak melakukan praktekmonopoli atau persaingan usaha tidak sehat. ${ }^{2}$

Perkembangan perekonomian di negara Indonesia harus diarahkan terwujudnya kesejahteraan rakyat berdasarkan Pancasila dan Undang-Undang Dasar Tahun 1945, terdapat di Pasal 33 ayat (4) Undang-Undang Dasar Tahun 1945 berisi ketentuan bahwa perekonomian nasional diselenggarakan berdasar atas demokrasi ekonomi dengan prinsip kebersamaan, efisiensi berkeadilan, berkelanjutan, berwawasan lingkungan, kemandirian, serta dengan menjaga keseimbangan kemajuan dan kesatuan ekonomi nasional. ${ }^{3}$

Ketentuan dalam Undang-Undang Dasar Tahun 1945 merupakan dasar negara yang harus dijadikan sebagai pedoman di negara Indonesia. Pemerintah mengundangkan Peraturan Perundang-undangan Nomor 5 Tahun 1999 tentang Larangan Praktek Monopoli dan Persaingan Usaha Tidak Sehat sebagai perwujudan dari Undang-Undang Dasar 1945 Pasal 33

\footnotetext{
${ }^{1}$ Rachmadi Usman, Hukum Persaingan Usaha Di Indonesia (Jakarta: Sinar Grafika, 2013).

${ }^{2}$ Hermansyah, Pokok-Pokok Hukum Persaingan Usaha Di Indonesia, 1st edn (Jakarta: Kencana, 2008).

${ }^{3}$ Redaksi Infra, Undang-Undang Dasar Republik Indonesia Tahun 1945 Dan Perubahannya (Indonesia), p. 52.
} 
Perlindungan Hukum Persaingan Usaha Terhadap

Indikasi Persekongkolan Tender Jack Up Drilling

Rig Service Antara Husky-CNOOC Madura Limited

dengan PT. COSL INDO

Suradiyanto; Dinny Wirawan

Pratiwie (4). Undang-Undang Persaingan Usaha bahwa ketentuan Pasal 3 menegaskan tujuan pembentukan Undang-Undang Persaingan Usaha yaitu:

1. Menjaga kepentingan umum dan meningkatkan efisiensi ekonomi nasional sebagai salah satu upaya untuk meningkatkan kesejahteraan rakyat.

2. Mewujudkan iklim usaha yang kondusif melalui pengaturan persaingan usaha yang sehat sehingga menjamin adanya kepastian kesempatan berusaha yang sama bagi pelaku usaha besar, pelaku usaha menengah dan pelaku usaha kecil.

3. Mencegah praktek monopoli dan persaingan usaha tidak sehat yang ditimbulkan oleh pelaku usaha.

4. Terciptanya efektivitas dan efisiensi dalam kegiatan usaha. ${ }^{4}$

Tujuan dari Undang-Undang Persaingan Usaha mengupayakan secara optimal terciptanya persaingan usaha yang sehat dan efektif pada suatu pasar, agar pelaku usaha melakukan efisiensi dan mampu bersaing dengan pelaku usaha lainnya. Fakta yang terjadi untuk menciptakan persaingan usaha yang sehat di negara Indonesia masih sulit diterapkan, terkait dengan alasan pelaku usaha lebih mementingkan keuntungan semata tetapi tidak memperhatikan aturan hukum yang berlaku. Undang-Undang Persaingan Usaha Pasal 1 angka 6 menentukan bahwa persaingan usaha tidak sehat adalah persaingan antar pelaku usaha dalam menjalankan kegiatan produksi dan atau pemasaran barang dan atau jasa yang dilakukan dengan cara tidak jujur atau melawan hukum atau menghambat persaingan. ${ }^{5}$

Perbuatan yang dilarang di Undang-Undang Nomor 5 Tahun 1999 tentang Larangan Praktek Monopoli dan/atau Persaingan Usaha Tidak Sehat salah satunya perjanjian kartel yaitu persekongkolan atau persekutuan diantara beberapa produsen produk sejenis dengan maksud untuk mengontrol produksi, harga dan penjualan serta untuk memperoleh posisi monopoli. ${ }^{6}$ Black law dictionary mengartikan kartel adalah suatu kerja sama dari produsenprodusen produk tertentu yang bertujuan untuk mengawasi produksi, penjualan dan harga untuk melakukan monopoli terhadap komoditas atau industri tertentu. ${ }^{7}$

Larangan membuat perjanjian kartel pada dasarnya diatur dalam Undang-Undang Persaingan Usaha Pasal 11 bahwa pelaku usaha dilarang membuat perjanjian dengan pelaku usaha saingannya yang bermaksud mempengaruhi harga dengan mengatur produksi dan atau pemasaran suatu barang dan atau jasa yang dapat mengakibatkan terjadi praktek monopoli dan persaingan usaha tidak sehat.

\footnotetext{
${ }^{4}$ Undang-Undang Tentang Larangan Praktek Monopoli Dan Persaingan Usaha Tidak Sehat (Indonesia, 1999).

${ }^{5}$ Undang-Undang Tentang Larangan Praktek Monopoli Dan Persaingan Usaha Tidak Sehat.

${ }^{6}$ Susanti Adi Nugroho, Hukum Persaingan Usaha Di Indonesia (Jakarta: Kencana, 2012).

${ }^{7}$ Usman.
} 
Perlindungan Hukum Persaingan Usaha Terhadap

Indikasi Persekongkolan Tender Jack Up Drilling

Rig Service Antara Husky-CNOOC Madura Limited

dengan PT. COSL INDO

Suradiyanto; Dinny Wirawan

Pratiwie Ketentuan Pasal 11 Undang-Undang Persaingan Usaha bertujuan untuk menghindari terjadinya praktek monopoli atau persaingan usaha yang tidak sehat. Larangan praktek sudah diatur Undang-Undang Nomor 5 Tahun 1999 tentang Larangan Praktek Monopoli dan Persaingan Usaha Tidak Sehat faktanya sering terjadi perjanjian kartel antar pelaku usaha baik pelaku usaha kecil, pelaku usaha menengah atau pelaku usaha besar. Negara Indonesia untuk melakukan pengawasan supaya tidak terjadi adanya perjanjian kartel yang merugikan pelaku usaha lain maupun konsumen adalah Komisi Pengawas Persaingan Usaha (KPPU). Lahirnya Undang-Undang Nomor 5 Tahun 1999 tentang Larangan Praktek Monopoli dan Persaingan Usaha Tidak Sehat yang kemudian juga melahirkan KPPU sebagai amanat daripada Undang-Undang Nomor 5 Tahun 1999 tentang Larangan Praktek Monopoli dan Persaingan Usaha Tidak Sehat apabila dipandang dalam sistem ketatanegaraan, KPPU merupakan lembaga negara komplementer (state auxiliary organ). ${ }^{8}$ Alasan yang dapat dikemukakan KPPU di bentuk karena hukum persaingan membutuhkan orang-orang yang spesialis yang memiliki latar belakang dan seluk beluk tentang bisnis dalam rangka menjaga mekanisme pasar. Institusi yang secara khusus menyelesaikan praktik monopoli dan persaingan usaha tidak sehat dapat dianggap suatu alternatif penyelesaian sengketa, sepanjang pengertian alternatif di hukum persaingan adalah diluar pengadilan. ${ }^{9}$

Undang-Undang Nomor 5 Tahun 1999 tentang Larangan Praktek Monopoli dan Persaingan Usaha Tidak Sehat Pasal 1 angka 18 berisi ketentuan komisi yang dibentuk untuk mengawasi pelaku usaha dalam menjalankan kegiatan usahanya agar tidak melakukan monopoli atau persaingan usaha tidak sehat. ${ }^{10}$

Dalam konteks ketatanegaraan, KPPU merupakan lembaga negara komplemen teruntuk melakukan penegakan hukum persaingan usaha berdasarkan Undang-Undang Nomor 5 Tahun 1999 tentang Larangan Praktek Monopoli dan Persaingan Usaha Tidak Sehat. Lembaga negara yang dibentuk diluar konstitusi dan merupakan lembaga yang membantu pelaksanaan tugas lembaga negara pokok (eksekutif, legislatif, yudikatif) sering juga disebut lembaga independen semu negara (quasi). ${ }^{11}$ Lembaga quasi menjalankan kewenangan yang sebenarnya sudah diakomodasi oleh lembaga negara yang sudah ada, tetapi dengan keadaan ketidakpercayaan publik (public distrust) kepada eksekutif, maka dipandang perlu dibentuk

\footnotetext{
${ }^{8}$ Budi L Kagramanto, 'Implementasi Undang-Undang Nomor 5 Tahun 1999 Oleh KPPU', Jurnal Ilmu Hukum Yustisia, 2007, 2.

${ }^{9}$ Nugroho.

${ }^{10}$ Undang-Undang Tentang Larangan Praktek Monopoli Dan Persaingan Usaha Tidak Sehat.

${ }^{11}$ Ahmad Fahmi Lubis and Dkk, Hukum Persaingan Usaha Antara Teks Dan Konteks (Jakarta: RDV Creative Media, 2009).
} 
Perlindungan Hukum Persaingan Usaha Terhadap

Indikasi Persekongkolan Tender Jack Up Drilling

Rig Service Antara Husky-CNOOC Madura Limited

dengan PT. COSL INDO

Suradiyanto; Dinny Wirawan

Pratiwie lembaga yang sifatnya independen. ${ }^{12}$ Kedudukan KPPU dalam sistem ketatanegaraan Indonesia juga dapat dilihat sebagai bagian demokratisasi penyelenggaraan pemerintahan yang saat ini cenderung mengalami pergeseran dari pola lama melalui tiga lembaga negara utama seperti yang dikemukakan Montesquieu. Keberadaan KPPU juga dapat ditafsirkan sebagai bentuk koreksi bagi penyelenggaraan kekuasaan oleh lembaga-lembaga negara sebelumnya yang dinilai berjalan tidak efektif.

Adapun kasus dalam penelitian ini adalah kasus persekongkolan tender Jack Up Drilling Rig Services antara Husky-CNOOC Madura Limited dengan PT Cosl Indo yang telah diputus oleh Putusan KPPU Nomor 03/KPPU-L/2016, sebagai berikut:

Dugaan Pelanggaran dilakukan oleh Para Terlapor adalah Pasal 22 Undang-Undang Nomor 5 Tahun 1999 sebagai berikut: Pelaku usaha dilarang bersekongkol dengan pihak lain untuk mengatur dan/atau menentukan pemenang tender sehingga dapat mengakibatkan terjadinya persaingan usaha tidak sehat.

Investigator dalam Laporan Dugaan Pelanggaran (LDP) maupun kesimpulannya dalam persidangan menyampaikan adanya dugaan persekongkolan antara Husky-CNOOC Madura Limited dan PT COSL INDO. Persekongkolan tersebut dapat dilihat dari adanya afiliasi antara PT COSL INDO dengan Husky-CNOOC Madura Limited, HUSKY-CNOOC Madura Limited mengundang PT ENSCO Sarida Offshore sebagai formalitas, membuat persyaratan Drill Pipe yang tidak lazim, PT COSL INDO tidak memenuhi persyaratan personil, dan adanya post-bidding.

Husky-CNOOC Madura Limited dalam tanggapannya atas Laporan Dugaan Pelanggaran dan Kesimpulan menyampaikan Husky-CNOOC Madura Limited tidak terafiliasi dengan PT COSL INDO, dan membantah semua dugaan pelanggaran yang disampaikan oleh investigator melalui tanggapan atas LDP dan kesimpulan.

PT COSL INDO dalam tanggapannya atas Laporan Dugaan Pelanggaran dan kesimpulan menyampaikan bahwa afiliasi CNOOC Group dan COSL Group dibenarkan menurut hukum yang berlaku dan membantah semua dugaan pelanggaran yang disampaikan oleh investigator melalui tanggapan atas LDP dan kesimpulan

Berdasarkan uraian di atas, maka dikemukakan rumusan permasalahan sebagai berikut:

\footnotetext{
12 Lubis and Dkk.
} 
Perlindungan Hukum Persaingan Usaha Terhadap

Indikasi Persekongkolan Tender Jack Up Drilling

Rig Service Antara Husky-CNOOC Madura Limited

dengan PT. COSL INDO

Suradiyanto; Dinny Wirawan

Prativie Bagaimana perlindungan hukum persaingan usaha terhadap indikasi persekongkolan Tender Jack Up Drilling Rig Services antara Husky-CNOOC Madura Limited dengan PT Cosl Indo?

2. Bagaimana pembuktian adanya persekongkolan Tender Jack Up Drilling Rig Services antara Husky-CNOOC Madura Limited dengan PT Cosl Indo dalam hukum persaingan usaha?

Berdasarkan apa yang telah dipaparkan pada latar belakang penelitian di atas, maka yang menjadi tujuan penelitian ini untuk mengetahui dan mengkaji perlindungan hukum persaingan usaha terhadap indikasi persekongkolan Tender Jack Up Drilling Rig Services antara Husky-CNOOC Madura Limited dengan PT Cosl Indo. Dan mengetahui dan mengkaji pembuktian adanya persekongkolan Tender Jack Up Drilling Rig Services antara HuskyCNOOC Madura Limited dengan PT Cosl Indo dalam hukum persaingan usaha.

\section{METODE PENELITIAN}

Tipe penelitian ini adalah penelitian hukum normatif. Penelitian hukum normatif mencakup antara lain penelitian terhadap prinsip-prinsup hukum, sistematika hukum dan konsistensi peraturan. Pendekatan yang digunakan dalam penelitian ini adalah:

1. Pendekatan perundang-undangan (statute approach), dilakukan dengan cara mengkaji peraturan perundang-undangan yang berkaitan dengan obyek penelitian, terutama Undang-Undang yang berkaitan dengan obyek penelitian ini.

2. Pendekatan konseptual (conceptual approach), dilakukan dengan mengkaji pendapat para sarjana yang digunakan sebagai pendukung.

3. Pendekatan perbandingan (comparative approach).

Bahan hukum primer yang digunakan adalah peraturan perundang-undangan yang berkaitan dengan obyek penelitian. Bahan hukum sekunder yang digunakan adalah dengan cara mempelajari, mengkaji dan menelaah bahan-bahan hukum yang berkaitan dengan penelitian. Bahan hukum primer dan sekunder diperoleh melalui studi pustaka.Bahan hukum yang diperoleh diklasifikasikan berdasarkan pokok masalah dalam penelitian ini, kemudian dilakukan sistematisasi untuk mempermudah dalam pemahaman.

Langkah analisis dalam penulisan tesis ini adalah dengan mengklasifikasikan bahan hukum yang diperoleh secara logis sistematis kemudian analisis dengan metode deskriptif analitis dan diinterprestasi sehingga diperoleh jawaban atas permasalahan dalam penelitian ini. 
Perlindungan Hukum Persaingan Usaha Terhadap

Indikasi Persekongkolan Tender Jack Up Drilling

Rig Service Antara Husky-CNOOC Madura Limited

dengan PT. COSL INDO

Suradiyanto; Dinny Wirawan

Pratiwie

\section{PEMBAHASAN}

\subsection{Pengertian dan Dasar Hukum Larangan Praktik Monopoli dan Persaingan Usaha Tidak Sehat}

Menurut Undang-Undang Nomor 5 Tahun 1999, monopoli didefinisikan sebagai suatu bentuk penguasan atas produksi dan atau pemasarang barang dan atau atas penggunaan jasa tertentu oleh satu pelaku atau satu kelompok pelaku usaha. Dalam Black's Law Dictionary, monopoli diartikan sebagai a privilege veted in one or more persons or companies, consisting in the exclusive right (or power) to carry on a particular business or trade, manufacture a particular article, or control the sale of the whole supply of a particular commodity. ${ }^{13}$ Berbeda dari definisi yang diberikan dalam undang-undang yang secara langsung menunjuk pada penguasaan pasar, dalam Black's Law Dictionary penekanan lebh diberikan pada adanya suatu hak istimewa (privilege) yang menghapuskan persaingan bebas, yang tentu pada akhirnya juga akan menciptakan penguasaan pasar. ${ }^{14}$

Selanjutnya dalam Black's Law Dictionary ${ }^{15}$ dikatakan Monopoly as prohibited by Section 2 of the Sherman Antitrust act, has two elements:

1. Possession of monopoly power in relevant market;

2. Willfull acquisition or maintenance of that power.

Dalam hal ini jelas bahwa Monopoli yang dilarang oleh Section 2 dari Sherman Act adalah monopoli yang bertujuan untuk menghilangkan kemampuan untuk melakukan persaingan dan atau untuk tetap mempertahankannya.

Hal ini memberikan konsekuensi dimungkinkan dan diperkenankan monopoli yang terjadi secara alamiah, tanpa adanya kehendak drai pelaku usaha tersebut untuk melakukan monopoli. Section 2 dari Sherman Act memang lebih menekankan pada proses terjadinya monopolitisasi dan bukan pada monopoli yang ada. Ada beberapa argumen yang dapat dikemukakan sehubungan dengan proses terjadinya monopoli secara alamiah. Hal-hal tersebut antara lain meliputi hal-hal berikut di bawah ini:

1. Monopoli terjadi sebagai akibat drai suatu superior skill, yang salah satunya dapat terwujud dari pemberian hak paten secara eksklusif oleh Negara, berdasarkan pada peraturan perundang-undangan yang berlaku kepada pelaku usaha tertentu atas hasil riset dan pengembangan atas teknologi tertentu. Selain itu ada juga yang dikenal dengan

\footnotetext{
${ }^{13}$ Ahmad Yani and Gunawan Widjaja, Seri Hukum Bisnis, Anti Monopoli (Jakarta: Rajawali Press, 1999).

${ }^{14}$ Yani and Widjaja.

${ }^{15}$ Yani and Widjaja.
} 
Perlindungan Hukum Persaingan Usaha Terhadap

Indikasi Persekongkolan Tender Jack Up Drilling

Rig Service Antara Husky-CNOOC Madura Limited

dengan PT. COSL INDO

Suradiyanto; Dinny Wirawan

Pratiwie

istilah trade secret, yang meskipun tidak memperoleh eksklusifitas pengakuan oleh Negara, namun dengan teknologi rahasianya mampu membuat suatu produk superior.

2. Monopoli terjadi karena pemberian Negara. Di Indonesia hal ini sangat jelas dapat dilihat dari pelaksanaan ketentuan Pasal 35 ayat (2) dan Pasal 33 ayat (3) UndangUndang Dasar 1945 yang dikutip kembali dalam Pasal 51 Undnag-Undang Nomor 5 Tahun 1999.

3. Monopoli terjadi karena suatu historical accident. Dikatakan sebagai historical accident oleh karena monopoli tersebut terjadi karena tidak sengaja dan berlangsung karena proses alamiah, yang ditentukan oleh berbagai factor terkait dimana monopoli tersebut terjadi. Dalam hal ini penilaian mengenai pasar bersangkutan yang memungkinkan terjadinya monopoli menjadi sangat relevan.

Selain definisi dari monopoli, dalam Undang-Undang Nomor 5 Tahun 1999 juga diberikan pengertian dari praktek monopoli, yaitu suatu pemusatan kekuatan ekonomi oleh satu atau lebih pelaku usaha yang mengakibatkan dikuasainya produksi dan atau pemasaran atas barang dan atau jasa tertentu sehingga menimbulkan persaingan usaha tidak sehat dan dapat merugikan kepentingan umum.

Dari definisi yang diberikan di atas dapat diketahui bahwa pada dasarnya ada 4 hal penting yang dapat dikemukakan tentang praktek monopoli ini yaitu:

1. Adanya pemusatan kekuatan ekonomi;

2. Pemusatan kekuatan tersebut berada pada satu atau lebih pelaku usaha ekonomi;

3. Pemusatan kekuatan ekonomi tersebut menimbulkan persaingan usaha tidak sehat; dan

4. Pemusatan kekuatan ekonomi tersebut merugikan kepentingan umum. ${ }^{16}$

Selanjutnya yang dimaksud dengan pemusatan kekuatan ekonomi adalah penguasaan yang nyata atas suatu pasar bersangkutan oleh satu atau lebih pelaku usaha sehingga dapat menentukan harga barang dan atau jasa; dan persaingan usaha tidak sehat adalah persaingan antar pelaku usaha dalam menjalankan kegiatan produksi dan atau pemasaran barang dan atau jasa yang dilakukan dengan cara tidak jujur atau melawan hokum atau menghambat persaingan usaha.

Satu hal yang menarik dari Undang-Undang Nomor 5 Tahun 1999 adalah bahwa selama suatu pemusatan kekuatan ekonomi tidak menyebabkan terjadinya persaingan usaha tidak sehat (sebagaimana didefinisikan), maka hal itu tidak dapat dikatakan telah terjadi suatu

\footnotetext{
${ }^{16}$ Yani and Widjaja.
} 
Perlindungan Hukum Persaingan Usaha Terhadap

Indikasi Persekongkolan Tender Jack Up Drilling

Rig Service Antara Husky-CNOOC Madura Limited

dengan PT. COSL INDO

Suradiyanto; Dinny Wirawan

Prativie
praktek monopoli, yang melanggar atau bertentangan dengan Undang-Undang Nomor 5

Tahun 1999, meskipun monopoli itu sendiri secara nyata-nyata telah terjadi (dalam bentuk penguasaan produksi dan/atau pemasaran barang dan/atau jasa tertentu). Jadi jelaslah bahwa monopoli itu sendiri tidak dilarang, yang dilarang adalah praktek monopoli dan persaingan usaha tidak sehat.

Dari pengertian yang diberikan di atas jelas dapat dilihat bahwa salah satu prasyarat pokok dapat dikatakan telah terjadi suatu pemusatan kekuatan ekonomi adalah telah terjadinya penguasaan nyata dari suatu pasar bersangkutan sehingga harga dari barang atau jasa yang diperdagangkan tidak lagi mengikuti hukum ekonomi mengenai permintaan dan penjualan, melainkan semata-mata ditentukan oleh satu atau lebih pelaku ekonomi yang menguasai pasar tersebut.

Untuk mencegah terjadinya persaingan usaha tidak sehat, yang menjurus ke arah terjadinya monopoli, undang-undang melarang dilakukan tindakan-tindakan tetentu oleh para pelaku usaha. Secara garis besar tindakan-tindakan tersebut dapat digolongkan ke dalam dua macam kategori. Pertama adalah tindakan yang dilakukan dalam rangka kerjasama dengan sesame pelaku usaha ekonomi, sebagaimana diatur dalam:

1. Pasal 4 dalam bentuk Oligopoli (dalam Black's Law Dictionary, oligopoly diartikan sebagai economic condition where only a few companies sell substantially similar or standardized products);

2. Pasal 5 sampai dengan Pasal 8 dalam bentuk penetapan harga secara bersama;

3. Pasal 9 dalam bentuk pembagian wilayah secara bersama;

4. Pasal 10 dalam bentuk kerjasama pemboikotan;

5. Pasal 11 dalam rangka pembentukan Kartel (menurut Black's Law Dictionary cartel is a combination of producers of any product joined together to control its production, sale and price, so as to obtain a monopoly and restrict competition in any particular industry or commodity);

6. Pasal 12 untuk Trust, dimana trust adalah an association or organization of persons or corporations having the invention and power, or the tendency, to create monopoly, control production, interfere with the free course of trade or transportation, or to fix and regulate the supply and the price of commodities (Black's Law Dictionary);

7. Pasal 13 dalam bentuk Oligopsoni;

8. Pasal 14 dalam rangka Integrasi Vertikal;

9. Pasal 15 dalam bentuk Perjanjian Tertutup;

10. Pasal 16 dalam bentuk Perjanjian dengan pihak di luar negeri. 
Perlindungan Hukum Persaingan Usaha Terhadap

Indikasi Persekongkolan Tender Jack Up Drilling

Rig Service Antara Husky-CNOOC Madura Limited

dengan PT. COSL INDO

Suradiyanto; Dinny Wirawan

Pratiwie Kedua, dalam bentuk tindakan atau perbuatan hukum yang dilakukan oleh pelaku usaha dan atau kelompok pelaku usaha tersebut tanpa melibatkan pelaku usaha atau kelompok pelaku usaha lainnya, yang dalam Undang-Undang Nomor 5 Tahun 1999 dibagi ke dalam:

1. Monopoli, yang diatur dalam Pasal 17;

2. Monopsoni, yang diatur dalam Pasal 18 (menurut Black's Law Dictionary Monopsony is a condition of the market in which there is but one buyer for a particular commodity);

3. Penguasaan Pasar, yang diatur dalam Pasal 19 sampai Pasal 21;

4. Persekongkolan, yang diatur dalam Pasal 22 sampai Pasal 24.

Pembagian yang demikian sejalan dengan aturan main yang juga ditetapkan dalam Sherman Act yang dikeluarkan tahun 1890, dimana ketentuan Seksi 1 Sherman Act berhubungan langsung dengan perjanjian, persekutuan maupun persekongkolan (yang melibatkan dua atau lebih pelaku usaha) yang menyebabkan hambatan dalam perdagangan (restraint in trade); dan Seksi 2 Sherman Act yang lebih menekankan pada kegiatan individual masing-masing pelaku usaha. Meksipun demikian kedua seksi tersebut secara bersama-sama melakukan pengawasan atas berbagai kegiatan yang bermaksud untuk melakukan control atas suatu pasar tertentu maupun yang bertujuan untuk mengurangi maupun menghilangkan kompetisi dalam pasar tersebut.

Gagasan untuk menerapkan Undang-Undang Antimonopoli dan mengharamkan kegiatan pengusaha yang curang telah dimulai sejak lima puluh tahun sebelum masehi. Peraturan Roma yang melarang tindakan pencatutan atau pengambilan keuntungan secara berlebihan, dan tindakan bersama yang mempengaruhi perdagangan jagung. Demikian pula Magna Charta yang ditetapkan tahun 1349 di Inggris telah pula mengembangkan prinsipprinsip yang berkaitan dengan restraint of trade atau pengekangan dalam perjanjian yang membatasi kebebasan individual untuk berkompetisi secara jujur.

Saat ini, bagi negara Indonesia pengaturan persaingan usaha bersumber pada UndangUndang Nomor 5 Tahun 1999 tentang Larangan Praktik Monopoli dan Persaingan Usaha Tidak Sehat, yang secara efektif berlaku pada 5 Maret 2000. Sesungguhnya keinginan untuk mengatur larangan praktik monopoli dan persaingan usaha tidak sehat dapat dijumpai dalam beberapa perundang-undangan yang ada.Praktik-praktik dagang yang curang (unfair trading practices) dapat dituntut secara pidana berdasarkan Pasal 382 bis Kitab Undang-Undang Hukum Pidana.Demikian pula pesaing yang dirugikan akibat praktik-praktik dagang yang curang tersebut, dapat menuntut secara perdata berdasarkan Pasal 1365 Kitab UndangUndang Hukum Perdata.Dalam bidang industri juga diharapkan tidak terjadi industri yang 
Perlindungan Hukum Persaingan Usaha Terhadap

Indikasi Persekongkolan Tender Jack Up Drilling

Rig Service Antara Husky-CNOOC Madura Limited

dengan PT. COSL INDO

Suradiyanto; Dinny Wirawan

Pratiwie
monopolistik dan tidak sehat, sebagaimana diamanat dalam Undang-Undang Nomor 15

Tahun 1984 tentang Perindustrian. Pasal 7 ayat (2) dan (3) Undang-Undang Nomor 15 Tahun 1984 tersebut menentukan bahwa pemerintah melakukan pengaturan, pembinaan dan pengembangan terhadap industri untuk mengembangkan persaingan yang baik dan sehat, mencegah persaingan tidak jujur, mencegah pemusatan industri oleh satu kelompok atau perseorangan, dan bentuk monopoli yang merugikan masyarakat.

Berdasarkan Undang-Undang Nomor 19 Tahun 1992 tentang Merek sebagaimana telah diubah dengan Undang-Undang Nomor 14 Tahun 1997, pemakai merek tanpa izin dapat dituntut secara perdata maupun pidana. Undang-Undang Nomor 40 Tahun 2007 tentang Perseroan Terbatas juga memuat ketentuan yang melarang penguasaan sumber ekonomi dan pemusatan kekuatan ekonomi pada suatu kelompok atau golongan tertentu melalui tindakan merger, konsolidasi, dan akuisisi perseroan; hal ini dapat dilakukan asalkan memperhatikan kepentingan perseroan, pemegang saham minoritas, dan karyawan perseroan, serta kepentingan masyarakat, termasuk pihak ketiga yang berkepentingan dan persaingan bisnis yang sehat dalam perseroan, mencegah monopoli dan monopsoni. Dengan demikian, bisa disimpulkan bahwa sebelum ada Undang-Undang Nomor 5 Tahun 1999, pengaturan larangan praktik monopoli dan persaingan usaha tidak sehat masih diatur secara parsial dan tersebar ke dalam berbagai perundang-undangan yang ada.

Realitanya, antara teori undang-undang dan praktik malah sama sekali bertolak belakang. Selama kurun waktu sekitar 15 (lima belas) tahun terakhir, perekonomian Indonesia dipenuhi tindakan-tindakan yang bersifat monopolistik dan tindakan-tindakan persaingan usaha yang curang (unfair business practices), misalnya pembentukan Badan Penyangga dan Pemasaran Cengkeh (BPPC) pada 1991 yang memberikan kewenangan tunggal untuk membeli cengkeh dari para petani cengkeh dan kewenangan menjalnya kepada para produsen rokok; dan Tata Niaga Jeruk ataupun PT Timor yang memperoleh banyak kemudahan fasilitas. Semua itu dengan dalih untuk pembangunan nasional dan menciptakan efisiensi, serta kemampuan bersaing walaupun realitanya tidak demikian. Hal itu terjadi karena kekuasaan Orde Baru terlalu kuat, baik di bidang sosial, politik, ekonomi, dan hukum.

Butir-butir yang tertera dalam Memorandum International Monetary Fund (IMF) tanggal 15 Januari 1998, khususnya yang mengacu pada pemaruan-pembaruan struktural, menunjukkan bahwa berbagai rintangan artifisial yang selama ini telah menghambat persaingan domestik telah atau akan dihapus oleh Pemerintah Indonesia. Akan tetapi di samping itu diperlukan pula Undang-Undang Persaingan Domestik yang Sehat, yang menetapkan asas-asas persaingan usaha yang sehat, yang tidak memberikan peluang bagi 
Perlindungan Hukum Persaingan Usaha Terhadap

Indikasi Persekongkolan Tender Jack Up Drilling

Rig Service Antara Husky-CNOOC Madura Limited

dengan PT. COSL INDO

Suradiyanto; Dinny Wirawan

Prativie
timbulnya rintangan-rintangan artifisial baru terhadap persaingan domestik di masa mendatang.

Undang-Undang Nomor 5 Tahun 1999 lebih tepat disebut sebagai Undang-undang "Antimonopoli dan Antipersaingan Usaha Curang" atau disingkat "antimonopoli" saja, bukannya "Larangan Praktik Monopoli dan Persaingan Usaha Tidak Sehat". Karena dengan menamakan atau menyebut Antimonopoli (dan Antipersaingan Usaha Curang) akan lebih jelas dan tegas, serta akan lebih mudah disosialisasikan kepada masyarakat daripada nama atau sebutan yang telah dipilih dalam undang-undang tersebut. Di samping itu, istilah antimonopoli (dan antipersaingan usaha curang atau antipersaingan curang) telah lebih dikenal dan memasyarakat di kalangan usahawan, akademis, dan praktisi hukum, sehingga pemahaman terhadap undang-undang itu akan lebih cepat dan lebih mudah diterapkan.

Istilah Undang-Undang Larangan Praktik Monopoli dan Persaingan Usaha Tidak Sehat selain terlalu panjang atau tidak ringkas, juga akan sulit diingat dan tidak mudah dipahami. Di samping itu, pasal-pasal tersebut tidak disusun dengan kalimat yang mudah dimengerti atau tidak disusun dengan tata cara perundang-undangan yang sewajarnya. Akibatnya, sosialisasi undang-undang itu akan mengalami kesulitan. Meskipun istilah "persaingan usaha tidak sehat" mungkin dianggap benar dari segi bahasa, dari segi hukum tidaklah demikian. Kata "tidak sehat" atau "sakit" sebagai lawan kata "sehat" lebih dekat pada atau lebih tepat digunakan untuk istilah "medis" daripada terminologi "hukum". Istilah "persaingan (usaha) curang” sebagai lawan kata "persaingan (usaha) jujur" akan lebih jelas dan tegas menurut istilah hukum dan ekonomi. Karena hukum, bagaimanapun memerlukan kata, kalimat, dan istilah yang tegas dan jelas, agar tidak menimbulkan interpretasi majemuk yang kemungkinan dapat mengakibatkan kepastian, keadilan, dan wibawa hukum itu tidak dapat ditegakkan.

Dalam Undang-Undang Nomor 5 Tahun 1999 tidak ditemukan ketentuan yang mengatur penyebutan nama singkat (citerrtitel) Undang-Undang Nomor 5 Tahun 1999. Sesuai dengan teknik perancangan undang-undang yang bersangkutan.

Di samping itu, Undang-Undang Nomor 5 Tahun 1999 dilengkapi pula dengan:

1. Penjelasan Umum;

2. Penjelasan Pasal demi Pasal

Dalam Penjelasan Umum Undang-Undang Nomor 5 Tahun 1999 dinyatakan bahwa secara umum, materi Undang-Undang Nomor 5 Tahun 1999 mengandung 6 (enam) bagian pengaturan yang terdiri atas: 
Perlindungan Hukum Persaingan Usaha Terhadap

Indikasi Persekongkolan Tender Jack Up Drilling

Rig Service Antara Husky-CNOOC Madura Limited

dengan PT. COSL INDO

Suradiyanto; Dinny Wirawan

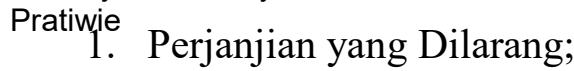

2. Kegiatan yang Dilarang;

3. Posisi Dominan;

4. Komisi Pengawas Persaingan Usaha;

5. Penegakan Hukum;

6. Ketentuan Lain-lain

\subsection{Perlindungan Hukum Persaingan Usaha Terhadap Indikasi Persekongkolan Tender} Jack Up Drilling Rig Services antara Husky-CNOOC Madura Limited dengan PT Cosl Indo

Adapun petikan putusan KPPU Nomor 03/KPPU-L/2016 tentang Persekongkolan Tender Jack Up Drilling Rig Services antara Husky-CNOOC Madura Limited dengan PT Cosl Indo, sebagai berikut:

Majelis Komisi (KPPU) telah melakukan Pembacaan Putusan Perkara Nomor 03/KPPU-L/2016 telah mengambil Putusan tentang Dugaan Pelanggaran Pasal 22 UndangUndang Nomor 5 Tahun 1999 terkait Tender/Lelang Jack-Up Drilling Rig Services for BD (Nomor: PT 2140720/PT 2140720R), yang dilakukan oleh:

1. Terlapor IHUSKY-CNOOC Madura Limited

2. Terlapor IIPT COSL INDO

Majelis Komisi menilai, setelah mendengarkan keterangan para Saksi, Ahli, Terlapor dan Investigator dalam persidangan yang terbuka umum, Unsur Pasal 22 Undang-Undang Nomor 5 Tahun 1999 telah Terpenuhi.

Sebelum memutus, Majelis Komisi merekomendasikan kepada Komisi untuk memberikan saran dan pertimbangan kepada Satuan Kerja Khusus Pelaksana Kegiatan Usaha Hulu Minyak dan Gas Bumi (SKK Migas) untuk:

1. Melakukan evaluasi terhadap aturan pengadaan (tender) terkait dengan keterkaitan kepemilikan saham antara penyedia barang dan/atau jasa dengan pengguna barang dan/atau jasa dalam proses tender yang sama karena dapat memicu terjadinya persekongkolan yang menghambat persaingan usaha;

2. Melakukan evaluasi terhadap aturan pengadaan (tender) terkait persyaratan Tingkat Kandungan Dalam Negeri (TKDN) yang lebih efektif dalam mencerminkan pencapaiannya sehingga tidak hanya sebatas pernyataan kesanggupan semata namun juga meliputi antara lain: metode atau strategi pencapaian dan komponen kegiatan dan barang yang lebih detail yang akan dipenuhi dalam rencana kegiatan. 
Perlindungan Hukum Persaingan Usaha Terhadap

Indikasi Persekongkolan Tender Jack Up Drilling

Rig Service Antara Husky-CNOOC Madura Limited

dengan PT. COSL INDO

Suradiyanto; Dinny Wirawan

Pratiwie Selanjutnya Majelis Komisi Perkara 03/KPPU-L/2016 menjatuhkan Putusan kepada para Terlapor sebagai berikut:

1. Menyatakan bahwa Terlapor I, Husky - CNOOC Madura Limited dan Terlapor II, PT COSL INDO terbukti secara sah dan meyakinkan melanggar Pasal 22 UndangUndang Nomor 5 Tahun 1999 tentang Larangan Praktek Monopoli dan Persaingan Usaha Tidak Sehat;

2. Menghukum Terlapor I, Husky - CNOOC Madura Limited membayar denda sebesar Rp. 12.800.000.000,00 (Dua Belas Milyar Delapan Ratus Juta Rupiah) yang harus disetor ke Kas Negara sebagai setoran pendapatan denda pelanggaran dibidang persaingan usaha Satuan Kerja Komisi Pengawas Persaingan Usaha melalui Bank Pemerintah dengan kode penerimaan 423755 (Pendapatan Denda Pelanggaran di Bidang Persaingan Usaha);

3. Menghukum Terlapor II, PT COSL INDO membayar denda sebesar Rp. 11.600.000.000,00 (Sebelas Milyar Enam Ratus Juta Rupiah) yang harus disetor ke Kas Negara sebagai setoran pendapatan denda pelanggaran dibidang persaingan usaha Satuan Kerja Komisi Pengawas Persaingan Usaha melalui Bank Pemerintah dengan kode penerimaan 423755 (Pendapatan Denda Pelanggaran di Bidang Persaingan Usaha);

4. Memerintahkan Terlapor I dan Terlapor II setelah melakukan pembayaran denda, maka salinan bukti bukti pembayaran denda tersebut dilaporkan dan diserahkan ke KPPU;

Demikian putusan ini ditetapkan melalui musyawarah dalam Sidang Majelis Komisi pada hari Selasa tanggal 25 Oktober 2016 oleh Majelis Komisi yang terdiri dari Dr. Syarkawi Rauf, S.E., M.Sc. sebagai Ketua Majelis Komisi; dan Saidah Sakwan, MA dan Ir. M. Nawir Messi, M.Sc. masing-masing sebagai Anggota Majelis Komisi, dan dibacakan di muka persidangan yang dinyatakan terbuka untuk umum pada hari Senin tanggal 14 November 2016 oleh Majelis Komisi yang terdiri dari Dr. Syarkawi Rauf, S.E., M.Sc. sebagai Ketua Majelis Komisi; Saidah Sakwan, MA sebagai Anggota Majelis Komisi dan Prof. Dr. Ir. Tresna Priyana Soemardi, S.E., M.S. sebagai Anggota Majelis Komisi Pengganti, dengan dibantu oleh Dewi Meryati, S.Kom. M.H Luqman Nurdiansyah, S.H. dan Melita Kristin, S.H.masing-masing sebagai Panitera.

Persekongkolan menggunakan berbagai cara untuk mengkoordinasikan kegiatan mereka, seperti melalui pengaturan produksi, penetapan harga secara horizontal, kolusi tender, pembagian wilayah, pembagian konsumen secara non-teritorial, dan pembagian pangsa pasar. 
Perlindungan Hukum Persaingan Usaha Terhadap

Indikasi Persekongkolan Tender Jack Up Drilling

Rig Service Antara Husky-CNOOC Madura Limited

dengan PT. COSL INDO

Suradiyanto; Dinny Wirawan

Pratiwie Akan tetapi perlu pula kita sadari bahwa persekongkolan yang efektif tidaklah mudah untuk dicapai. Bagaimanapun terdapat kecenderungan para pelaku usaha akan selalu berusaha memaksimalkan keuntungan perusahaannya masing-masing.

Harus ada beberapa syarat dalam terjadinya sebuah persekongkolan adalah harus adanya kesepakatan perjanjian atau kolusi antara pelaku usaha. Ada dua bentuk kolusi dalam persekongkolan, yaitu: Kolusi eksplisit, dimana para anggota mengkomunikasikan dan mengkoordinasikan kesepakatan mereka secara nyata/langsung yang bisa dinyatakan dengan beberapa dokumen perjanjian yang sudah mereka sepakati, data mengenai audit bersama, kepengurusan persekongkolan, kebijakan- kebijakan tertulis, data penjualan dan data-data lainnya. Ada juga kolusi diam-diam, dimana para pelaku usaha anggota persekongkolan tidak mengkomunikasi secara terang-terangan, biasanya pertemuan-pertemuan juga diadakan secara rahasia. Dan biasa yang digunakan sebagai media adalah asosiasi industri, sehingga pertemuan-pertemuan anggota persekongkolan dikamuflasekan dengan pertemuan-pertemuan yang legal seperti pertemuan asosiasi. Bentuk kolusi yang kedua ini sangat sulit untuk dideteksi oleh penegak hukum. Namun pengalaman dari berbagai negara membuktikan bahwa setidaknya $30 \%$ persekongkolan adalah melibatkan asosiasi.

Selanjutnya penjelasan indikasi persekongkolan, sebagaimana yang diserahi tugas oleh Undang-Undang untuk mengawasi persaingan usaha yang berda di Indonesia, sehingga KPPU mempunyai tanggung jawab untuk mencegah dan menindak perilaku persekongkolan di Indonesia. KPPU sebagaimana dirumuskan dalam Pasal 22-24 UU No 5/1999, mempunyai kewenangan melakukan penegakan hukum perkara persekongkolan baik berdasarkan atas inisiatif KPPU sendiri atau atas dasar laporan dari masyarakat. Indikator Awal Identifikasi persekongkolan Untuk memenuhi persyaratan bukti awal yang cukup, KPPU dapat memeriksa beberapa indikator awal yang dapat disimpulkan sebagai faktor pendorong terbentuknya persekongkolan. Secara teori, ada beberapa faktor yang dapat mendorong atau memfasilitasi terjadinya persekongkolan baik faktor struktural maupun perilaku.

Secara umum, ketentuan ini sangat berguna sebagai informasi terhadap masyarakat khususnya pelaku usaha agar benar-benar mengetahu indikasi awal apa saja yang dapat dikategorikan kegiatan persekongkolan. Dan juga ini dapat menjadi proses pembelajar guna menyempurnakan lagi cara-cara mengidentasikan perbuatan persekongkolan tersebut, sehingga suatu saat pihak-pihak terkait khususnya konsumen dapat menggugat atau paling tidak mengetahui dan melapor perbuatan pelaku usaha yang terindikasi persekongkolan tersebut sebab akibat dari persekongkolan yang sudah diuraikan penulis sangat merugikan konsumen terlebih-lebih negara. 
Perlindungan Hukum Persaingan Usaha Terhadap

Indikasi Persekongkolan Tender Jack Up Drilling

Rig Service Antara Husky-CNOOC Madura Limited

dengan PT. COSL INDO

Suradiyanto; Dinny Wirawan

Pratiwie

Karena sudah tidak bisa sesuai dengan konsep dasar perekonomian nasional Indonesia yaitu demokrasi ekonomi dalam wujud kerakyatan. Jika sampai terjadi persaingan usaha sehat dan adil yang terjadi di industri apapun di Indonesia tercinta kita ini, jangan heran tercipta inovasi-inovasi baru dalam dunia industri kita dan Indonesia bukan negara konsumtif lagi dan masysrakat sangat diuntungkan. Sayangnya, tidak jarang tindakan persekongkolan difasilitasi kebijakan pemerintah dalam bentuk peraturan perundang-undangan, sehingga kegiatan tersebut seolah-olah memiliki pembenaran yuridis.

\subsection{Pembuktian Adanya Persekongkolan Tender Jack Up Drilling Rig Services antara} Husky-CNOOC Madura Limited dengan PT Cosl Indo Dalam Hukum Persaingan Usaha

Hukum pembuktian adalah seperangkat kaidah hukum yang mengatur tentang pembuktian, yakni segala proses, dengan menggunakan alat-alat bukti yang sah, dilakukan tindakan dengan prosedur khusus, dan guna mengetahui fakta di persidangan. ${ }^{17}$ Pembuktian di perlukan dalam suatu perkara yang mengadili suatu sengketa di muka pengadilan (juridicto contentiosa) maupun dalam perkara-perkara permohonan yang menghasilkan suatu penetapan (juridicto voluntair). ${ }^{18}$

Secara teoritis perilaku penetapan harga merupakan bentuk nyata dari koordinasi yang dilakukan oleh perusahaan-perusahaan yang ada di pasar atau asosiasi dagang untuk memperoleh hasil kolusi. Dengan demikian pemahaman mengenai pembuktian terhadap pelanggaran Pasal 22 mengenai persekongkolan. Dalam perkara persekongkolan yang penulis teliti ini KPPU sudah memutuskan kepada Husky-CNOOC Madura Limited dan PT Cosl Indo telah melanggar Pasal 22 UU No.5/1999.

Permasalahan yang muncul di masyarakat khususnya peradilan di Indonesia dalam tata cara tentang pembuktian dan pengungkapan persekongkolanini adalah adanya perdebatan istilah hard evidence/bukti langsung dan circumstantial evidence/bukti tidak langsung. Hingga saat ini belum terdapat penjelasan yang jelas dan kongkrit didalam dua jenis maupun istilah yang terdapat dalam alat bukti tersebut dikaitkan dengan sistem pembuktian dalam peraturan perundang-undangan di Indonesia tetapi di negara-negara uni eropa seudah menggunakan pembuktian secara tidak langsung sebagai cara pembuktian suatu kegitan usaha yang melakukan persekongkolan.

\footnotetext{
${ }^{17}$ Munir Fuady, Teori Hukum Pembuktian (Pidana Dan Perdata) (Bandung: Citra Aditya Bakti, 2006).

${ }^{18}$ Devi Meylina, Hukum Persaingan Usaha Studi Konsep Pembuktian Terhadap Perjanjian Penetapan Harga Dalam Persaingan Usaha (Malang: Setara Press, 2013).
} 
Perlindungan Hukum Persaingan Usaha Terhadap

Indikasi Persekongkolan Tender Jack Up Drilling

Rig Service Antara Husky-CNOOC Madura Limited

dengan PT. COSL INDO

Suradiyanto; Dinny Wirawan

Pratiwie Adanya circumstantial evidence/bukti tidak langsung karena bukti langsung menjadi semakin sulit ditemukan karena keberadaan pengawas persaingan usaha telah menjadi faktor yang telah di perhitungkan sehingga hal-hal yang berkaitan dengan bukti langsung telah dihindari oleh pelaku usaha. ${ }^{19}$ Biasanya tindakan kartel dilakukan secara tertutup dan bersifat rahasia, sehingga pembuktian terhadap kartel bukanlah pekerjaan yang mudah. Meskipun demikian penggunaan alat anlisis ekonomi menjadi salah satu kunci penting dalam penggunan bukti tidak langsung untuk membuktikan adanya suatu pembuktian. Pada dasarnya analisis secara ekonomi untuk pembuktian persekongkolanmaupun perjanjian penetapan harga adalah untuk:

1. Membuktikan apakah perilaku perusahaan rasional meskipun tanpa ada kolusi. Hal ini diperlukan untuk mengesampingkan kemungkinan prilaku yang konsisten dengan kondisi persaingan.

2. Membuktikan apakah struktur pasar mendukung terjadinya suatu kolusi.

3. Membuktikan apakah karakteristik pasar konsisten sebagai fasilitas kolusi

4. Membuktikan apakah kinerja di pasar merupakan dugaan atas perjanjian penetapan harga.

5. Membandingkan kondisi yang terjadi akibat adanya suatu perjanjian kolusi dengan kondisi yang muncul dari persaingan.

Pembuktian dari analisa ekonomi diatas digunakan untuk menyimpulkan apakah kondisi di pasar mendukung untuk kesuksesan sebuah koalisi (prerequistes for successful collusion). Jika iya, maka bukti-bukti tidak langsung dapat digunakan untuk menduga adanya kordinasi di pasar sehingga dapat dijadikan petunjuk adanya penyelenggaran terhadap Pasal 22 UU No.5/1999.

Pedoman tentang persekongkolan mencoba memberikan petunjuk pelaksanaan membuktikan dan menentukan unsur-unsur adanya persekongkolanantara lain bahwa UU No.5/1999 mengamanatkan penggunaan metode pendekatan Rule of Reason. Hukum Persaingan mengenal dua pendekatan hukum, per se illegal dan rule of reason. Pendekatan rule of reason adalah suatu pendekatan yang digunakan oleh lembaga otoritas persaingan usaha untuk membuat perubahan tentang akibat kesepakatan perjanjian dan juga kegiatan usaha tertentu untuk menentukan apakah perjanjian maupun kegiatan tersebut akan

\footnotetext{
${ }^{19}$ Meylina.
} 
Perlindungan Hukum Persaingan Usaha Terhadap

Indikasi Persekongkolan Tender Jack Up Drilling

Rig Service Antara Husky-CNOOC Madura Limited

dengan PT. COSL INDO

Suradiyanto; Dinny Wirawan

Pratiwie menghambat persaingan atau malah menghambat persaingan. ${ }^{20}$ Sebaliknya, pendekatan per se illegal adalah menyatakan setiap perjanjian atau kegiatan usaha tertentu sebagai ilegal, tanpa pembuktian lebih lanjut atas dampak yang ditimbulkan dari perjanjian atau kegiatan usaha tersebut. Kegiatan yang dianggap sebagai per se illegal biasanya meliputi penetapan harga secara kolusif atas produk tertentu, serta pengaturan harga penjualan kembali.

Secara umum, terdapat dua metode pendekatan untuk membuktikan/mendeteksi kartel, yakni Metode Reaktif dan Metode Proaktif. Metode Reaktif adalah metode yang pada dasarnya terdapat dalam beberapa kedaan dari luar yang sudah pernah terjadi sebelum otoritas persaingan usaha/KPPU mengetahui adanya kemungkinan atas issue persekongkolandan akan melaksanakan suatu investigasi terhadap issue tersebut.

Metode lainnya adalah Metode Proaktif, metode ini melakukan pendekatan yang diakli/dilaksankan atas dasar perintah dari otoritas persaingan usaha/KPPU itu sendiri untuk mengetahui apakah kegiatan persekongkolantersebut benar-benar terjadi atau tidak, juga tidak akan ada kaitannya dengan peristiwa eksternal. Biasanya penggunaan metode ini adalah dengan mengunakan analisa tentang pasar, melakukan monitoring kegiatan industri tersebut, juga melakukan penelusuran melalu media cetak mauun elektronik, bahkan bertukar pengalaman dengan otoritas persaingan usaha dari negara lainnya. Selain itu ada macammacam alasan kenapa otoritas persaingan usaha harus menggunakan metode proaktif ini alasan utamanya adalah otoritas persaingan usaha ini bersifat independen atau bebas dalam mengambil langkah pendikteksian/pembuktian awal terjadinya persekongkolan tersebut. Meskipun dalam hal pembuktian yang dilakukan oleh otoritas persaingan usaha/KPPU kekurangan dan kehilangan informasi mengenai persekongkolan, maka pendikteksian/pembuktian tetap dilanjutkan.

Tetapi dalam perkara indikasi persekongkolanpihak otoritas persaingan usaha/KPPU menggunakan metode Harrington, Dan pengertian dari Metode Harrington ini adalah bergabungnya macam-macam metode yakni metode yang melihat persekongkolan dari berbagai macam sisi agar perilaku persekongkolan yang dilakukan pelaku usaha terlihat jelas dengan cara pendekatan ilmu pengetahuan ekonomi yaitu dengan menggunakan cara metode analisis hubungan error atau residual regresi antar perusahaan dari hasil estimasi data panel tersebut. Jika kita lihat dalam ekonometrika, error atau residual regresi ini akan selalu menjadi dasar untuk melihat perilaku pelaku usah dari suatu persekongkolan. Biasanya juga

\footnotetext{
${ }^{20}$ A.M. Tri Anggraini, 'Mekanisme, Menditeksi Dan Mengungkap Kartel Dalam Hukum Persaingan', 2011 <http://sekartrisakti.wordpress.com/2011/06/08/mekanisme-menditeksi-dan-mengungkap-kartel-dalamhukum-persaingan/ >.
} 
Perlindungan Hukum Persaingan Usaha Terhadap

Indikasi Persekongkolan Tender Jack Up Drilling

Rig Service Antara Husky-CNOOC Madura Limited

dengan PT. COSL INDO

Suradiyanto; Dinny Wirawan

Pratiwie

para ahli dibidang ekonometrika ini menggunakan analisis perilaku dan juga menggunakan pola residual baik antar waktu maupun antar individu.

\section{KESIMPULAN}

Persekongkolan menggunakan berbagai cara untuk mengkoordinasikan kegiatan mereka, seperti melalui pengaturan produksi, penetapan harga secara horizontal, kolusi tender, pembagian wilayah, pembagian konsumen secara non-teritorial, dan pembagian pangsa pasar. Akan tetapi perlu pula kita sadari bahwa persekongkolan yang efektif tidaklah mudah untuk dicapai. Bagaimanapun terdapat kecenderungan para pelaku usaha akan selalu berusaha memaksimalkan keuntungan perusahaannya masing-masing. Harus ada beberapa syarat dalam terjadinya sebuah persekongkolan adalah harus adanya kesepakatan perjanjian atau kolusi antara pelaku usaha.

Pedoman tentang persekongkolan mencoba memberikan petunjuk pelaksanaan membuktikan dan menentukan unsur-unsur adanya persekongkolan antara lain bahwa UU No. 5/1999 mengamanatkan penggunaan metode pendekatan Rule of Reason. Hukum Persaingan mengenal dua pendekatan hukum, per se illegal dan rule of reason. Pendekatan rule of reason adalah suatu pendekatan yang digunakan oleh lembaga otoritas persaingan usaha untuk membuat perubahan tentang akibat kesepakatan perjanjian dan juga kegiatan usaha tertentu untuk menentukan apakah perjanjian maupun kegiatan tersebut akan menghambat persaingan atau malah menghambat persaingan. Sebaliknya, pendekatan per se illegal adalah menyatakan setiap perjanjian atau kegiatan usaha tertentu sebagai ilegal, tanpa pembuktian lebih lanjut atas dampak yang ditimbulkan dari perjanjian atau kegiatan usaha tersebut. Kegiatan yang dianggap sebagai per se illegal biasanya meliputi penetapan harga secara kolusif atas produk tertentu, serta pengaturan harga penjualan kembali.

\section{REFERENSI}

Anggraini, A.M. Tri, 'Mekanisme, Menditeksi Dan Mengungkap Kartel Dalam Hukum Persaingan', $2011<$ http://sekartrisakti.wordpress.com/2011/06/08/mekanismemenditeksi-dan-mengungkap-kartel-dalam-hukum-persaingan/ >

Fuady, Munir, Teori Hukum Pembuktian (Pidana Dan Perdata) (Bandung: Citra Aditya Bakti, 2006)

Hermansyah, Pokok-Pokok Hukum Persaingan Usaha Di Indonesia, 1st edn (Jakarta: Kencana, 2008)

Kagramanto, Budi L, 'Implementasi Undang-Undang Nomor 5 Tahun 1999 Oleh KPPU', Jurnal Ilmu Hukum Yustisia, 2007, 2

Lubis, Ahmad Fahmi, and Dkk, Hukum Persaingan Usaha Antara Teks Dan Konteks (Jakarta: 
Perlindungan Hukum Persaingan Usaha Terhadap

Indikasi Persekongkolan Tender Jack Up Drilling

Rig Service Antara Husky-CNOOC Madura Limited

dengan PT. COSL INDO

Suradiyanto; Dinny Wirawan

Pratiwie RDV Creative Media, 2009)

Meylina, Devi, Hukum Persaingan Usaha Studi Konsep Pembuktian Terhadap Perjanjian Penetapan Harga Dalam Persaingan Usaha (Malang: Setara Press, 2013)

Nugroho, Susanti Adi, Hukum Persaingan Usaha Di Indonesia (Jakarta: Kencana, 2012)

Redaksi Infra, Undang-Undang Dasar Republik Indonesia Tahun 1945 Dan Perubahannya (Indonesia), p. 52

Undang-Undang Tentang Larangan Praktek Monopoli Dan Persaingan Usaha Tidak Sehat (Indonesia, 1999)

Usman, Rachmadi, Hukum Persaingan Usaha Di Indonesia (Jakarta: Sinar Grafika, 2013)

Yani, Ahmad, and Gunawan Widjaja, Seri Hukum Bisnis, Anti Monopoli (Jakarta: Rajawali Press, 1999) 